\title{
Effect of Liquid Phase on Sintering of Magnesium Oxide with Zirconium Diphosphate Addition
}

\author{
Kiyoshi ITATANI, Akira KISHIOKA and Makio KINOSHITA \\ (Department of Chemistry, Faculty of Science and Technology, Sophia University \\ 7-1, Kioi-cho, Chiyoda-ku, Tokyo 102
}

\begin{abstract}
The sintering of $\mathrm{MgO}$ with $\mathrm{ZrP}_{2} \mathrm{O}_{7}$ additions in the concentrations of $0.1,0.5,1.0$ and 3.0 $\mathrm{mol} \%$ was studied in the presence of the liquid phase at increasing temperatures (room temperature to $1450^{\circ} \mathrm{C}$ ) and at a constant temperature $\left(1450^{\circ} \mathrm{C}, 5 \mathrm{~h}\right.$ ). The densification of the $\mathrm{MgO}$ compact was inhibited above $1300^{\circ} \mathrm{C}$ by the addition of $1.0 \mathrm{~mol} \%$ or less of $\mathrm{ZrP}_{2} \mathrm{O}_{7}$, whereas it was promoted by $3.0 \mathrm{~mol} \% \mathrm{ZrP}_{2} \mathrm{O}_{7}$ addition. The difference in the densification behavior was considered to be due to variations in the amount of the liquid phase present in the $\mathrm{MgO}-\mathrm{Mg}_{3}\left(\mathrm{PO}_{4}\right)_{2}$ system above $1300^{\circ} \mathrm{C}:$ an amount of the liquid phase sufficient to spread over the grains promoted the densification of the $\mathrm{MgO}$ compact through accelerating the rearrangement of the grains and through eliminating the open pores.
\end{abstract}

[Received November 24, 1983]

\section{ニリン酸ジルコニウムを添加した酸化マグネシウムの 焼結に及ぼす液相の影響}

\author{
板 谷清司・岸 岡 昭・木下真喜雄
}

(上智大学 理工学部 化学科)

\begin{abstract}
$\mathrm{ZrP}_{2} \mathrm{O}_{7}$ を $0.1 \mathrm{~mol} \%, 0.5 \mathrm{~mol} \%, 1.0 \mathrm{~mol} \%$ 及び $3.0 \mathrm{~mol} \%$ の濃度で添加した $\mathrm{MgO}$ 試験片に ついて, 液相が存在するときの焼結挙動を昇温法 (室温 $1450^{\circ} \mathrm{C}$ ) 及び定温法 $\left(1450^{\circ} \mathrm{C}, 5 \mathrm{~h}\right)$ によっ て検討した。

$\mathrm{MgO}$ のち密化は $\mathrm{ZrP}_{2} \mathrm{O}_{7}$ が $1.0 \mathrm{~mol} \%$ 以下の添加量において $1300^{\circ} \mathrm{C}$ 以上で抑制されたが， 3.0 $\mathrm{mol} \%$ 添加試料においてそれは促進された. $\mathrm{MgO}$ のち密化挙動が $\mathrm{ZrP}_{2} \mathrm{O}_{7}$ の添加量によって異な るのは $1300^{\circ} \mathrm{C}$ 以上で生成する $\mathrm{MgO}-\mathrm{Mg}_{3}\left(\mathrm{PO}_{4}\right)_{2}$ 系液相量の違いによるものと考えられた。すなお

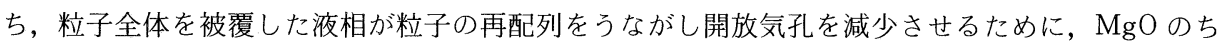
密化が促進されることが分った.

(1983 年 11 月 24 日受付)
\end{abstract}

Key-words : Magnesium oxide, Zirconium diphosphate addition, Sintering, Liquid phase

\section{Introduction}

Magnesium oxide $(\mathrm{MgO})$ is often used practically as a representative basic refractory. $\mathrm{MgO}$ refractories are generally produced with a small amount of additive introduced for the purpose of promoting the densification ${ }^{11}$.

Phosphoric acid $\left(\mathrm{H}_{3} \mathrm{PO}_{4}\right)$ is well-known as a typical phosphate additive; however, it can not be used for the $\mathrm{MgO}$ refractory because of a violent reaction of $\mathrm{MgO}$ with $\mathrm{H}_{3} \mathrm{PO}_{4}{ }^{2}$. Instead of $\mathrm{H}_{3} \mathrm{PO}_{4}$, therefore, metal phosphates and metal acid phosphates are employed for additives $^{3 /-5)}$.

The authors have already been investigated the effects of some metal diphosphates, such as $\mathrm{Mg}_{2} \mathrm{P}_{2} \mathrm{O}_{7}, \mathrm{Ca}_{2} \mathrm{P}_{2} \mathrm{O}_{7}, \quad \mathrm{SiP}_{2} \mathrm{O}_{7}$ and $\mathrm{ZrP}_{2} \mathrm{O}_{7}$, on the sintering of $\mathrm{MgO}^{6(-8)}$. The densification of $\mathrm{MgO}$ was promoted with the above diphosphates addition via (1) mass transfer accelerated by the reaction between $\mathrm{MgO}$ and an additive and 
(2) the liquid phase formed by the fusion of the reaction products.

In our previous papers, the sintering of $\mathrm{MgO}$ with $\mathrm{ZrP}_{2} \mathrm{O}_{7}$ addition was investigated up to $1300^{\circ} \mathrm{C}^{6}$. In the $\mathrm{MgO}-\mathrm{ZrP}_{2} \mathrm{O}_{7}$ system, however, an appreciable amount of liquid is expected to form above $1300^{\circ} \mathrm{C}$.

The purpose of this study is to clarify the role of the liquid phase on the sintering of $\mathrm{MgO}$ with $\mathrm{ZrP}_{2} \mathrm{O}_{7}$ addition in the temperature region of $1300^{\circ} \mathrm{C}$ to $1450^{\circ} \mathrm{C}$.

\section{Experimental}

\section{1 Materials and sample preparations}

$\mathrm{MgO}$ was obtained by heating $\mathrm{Mg}(\mathrm{OH})_{2}$ (Kanto Chemicals Co., Inc.) at $900^{\circ} \mathrm{C}$ for $1 \mathrm{~h}$. $\mathrm{ZrP}_{2} \mathrm{O}_{7}$ was prepared as follows ${ }^{6)}: \mathrm{ZrO}\left(\mathrm{NO}_{3}\right)_{2}$ solution was mixed with a little excess of $\mathrm{H}_{3} \mathrm{PO}_{4}$ $(85 \%)$ to form a zirconium bis (hydrogen phosphate) hydrate $\left(\mathrm{Zr}\left(\mathrm{HPO}_{4}\right)_{2} \cdot n \mathrm{H}_{2} \mathrm{O}\right)$. The product was then heated at $1050^{\circ} \mathrm{C}$ for $5 \mathrm{~h}$ to obtain $\mathrm{ZrP}_{2} \dot{\mathrm{O}}_{7}$.

$\mathrm{ZrP}_{2} \mathrm{O}_{7}$ was mixed with $\mathrm{MgO}$ in the concentrations of $0,0.1,0.5,1.0$ and $3.0 \mathrm{~mol} \%$ : part of the obtained mixture was pressed into disks ( 5 $\mathrm{mm}$ diam. and $3 \mathrm{~mm} \mathrm{high)} \mathrm{at} 3000 \mathrm{~kg} \cdot \mathrm{cm}^{-2}$, and part into rectangular solids $(7 \mathrm{~mm}$ by $10 \mathrm{~mm}$ by $70 \mathrm{~mm}$ ) at $500 \mathrm{~kg} \cdot \mathrm{cm}^{-2}$. The former were used for the measurements of shrinkages and the latter for the measurements of other properties.

\section{2 Shrinkages}

Shrinkages of $\mathrm{MgO}$ compacts with $\mathrm{ZrP}_{2} \mathrm{O}_{7}$ addition were measured by using a dilatometer from room temperature up to $1450^{\circ} \mathrm{C}$ at increasing temperatures of $10^{\circ} \mathrm{C} \cdot \mathrm{min}^{-1}$ in air. Differential thermal analysis (DTA) was also carried out under the same heating conditions.

\section{3 Relative density and porosities}

$\mathrm{MgO}$ compacts with various amounts of $\mathrm{ZrP}_{2} \mathrm{O}_{7}$ addition were placed on platinum foils and inserted into an electric furnace ( $\mathrm{SiC}$ ). They were heated at $1450^{\circ} \mathrm{C}$ for $5 \mathrm{~h}$ and then were quenched to room temperature.

The relative density, the total porosity, the open porosity and the closed porosity of sintered samples were determined by the conventional methods reported previously ${ }^{9), 10}$.

\section{4 Phase identification}

The crystalline phases formed during sintering were identified by using powder X-ray diffractometry with $\mathrm{Ni}$-filtered $\mathrm{Cu} K \alpha$ radiation, operating at $40 \mathrm{kV}$ and $30 \mathrm{~mA}$.

\section{5 SEM observation and EPMA}

The observation of scanning electron microscopy (SEM) and electron probe X-ray microanalysis (EPMA) for sintered samples were performed under the conditions reported previously ${ }^{7)}$. Samples for SEM observations were etched by concentrated $\mathrm{HNO}_{3}$ at $0^{\circ} \mathrm{C}$ for 90 minutes.

\section{Results and discussion}

\section{1 Densification process of $\mathrm{MgO}$ with $\mathrm{ZrP}_{2} \mathrm{O}_{7}$ addition}

It is important to make clear the relationship between the phase changes and the densification during sintering.

We have reported that $\mathrm{MgO}$ reacted with $\mathrm{ZrP}_{2} \mathrm{O}_{7}$ to form monoclinic $\mathrm{ZrO}_{2}$, tetragonal $\mathrm{ZrO}_{2}$ and $\mathrm{Mg}_{3}\left(\mathrm{PO}_{4}\right)_{2}$ from $900^{\circ} \mathrm{C}$ to $1300^{\circ} \mathrm{C}$. Figure 1 shows the $\mathrm{X}$-ray diffraction pattern of $\mathrm{MgO}$ with $3.0 \mathrm{~mol} \% \mathrm{ZrP}_{2} \mathrm{O}_{7}$ addition sintered at $1450^{\circ} \mathrm{C}$ for $5 \mathrm{~h}$. Two kinds of products were observed : cubic $\mathrm{ZrO}_{2}$ and $\mathrm{Mg}_{3}\left(\mathrm{PO}_{4}\right)_{2}$. The lattice constant of the cubic $\mathrm{ZrO}_{2}$ was about $5.076 \AA$, which is in good accord with that of the $\mathrm{ZrO}_{2}$ stabilized by $\mathrm{MgO}^{11}$. The presence of the cubic $\mathrm{ZrO}_{2}$ is therefore considered to be due to the solid-solution of $\mathrm{MgO}$ into $\mathrm{ZrO}_{2}$.

The DTA curve of $\mathrm{MgO}$ with $3.0 \mathrm{~mol} \%$ $\mathrm{ZrP}_{2} \mathrm{O}_{7}$ addition showed weak endothermic effects at $1172^{\circ}-1295^{\circ} \mathrm{C}$ and $1394^{\circ}-1418^{\circ} \mathrm{C}$. From the phase diagram of $\mathrm{MgO}-\mathrm{P}_{2} \mathrm{O}_{5}$ system ${ }^{12)}$ the first endothermic effect is attributable to the formation of the liquid phase in the $\mathrm{Mg}$ $\left(\mathrm{PO}_{3}\right)_{2}-\mathrm{Mg}_{2} \mathrm{P}_{2} \mathrm{O}_{7}$ system and the secund effect to the formation of the liquid phase in the $\mathrm{MgO}-\mathrm{Mg}_{3}\left(\mathrm{PO}_{4}\right)_{2}$ system. In these systems, the crystalline compounds of both $\mathrm{Mg}\left(\mathrm{PO}_{3}\right)_{2}$ and $\mathrm{Mg}_{2} \mathrm{P}_{2} \mathrm{O}_{7}$ could not be detected by X-ray

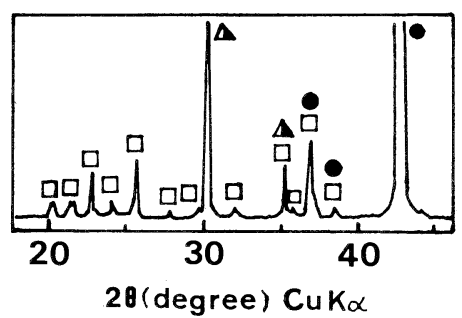

Fig. 1. Powder X-ray diffraction pattern of $\mathrm{MgO}$ with $3.0 \mathrm{~mol} \% \mathrm{ZrP}_{2} \mathrm{O}_{7}$ addition heated at $1450^{\circ} \mathrm{C}$ for $5 \mathrm{~h}$.

: $\mathrm{MgO}, \boldsymbol{\Delta}: \mathrm{ZrO}_{2}$ (cubic), $\square: \mathrm{Mg}_{3}\left(\mathrm{PO}_{4}\right)_{2}$ 


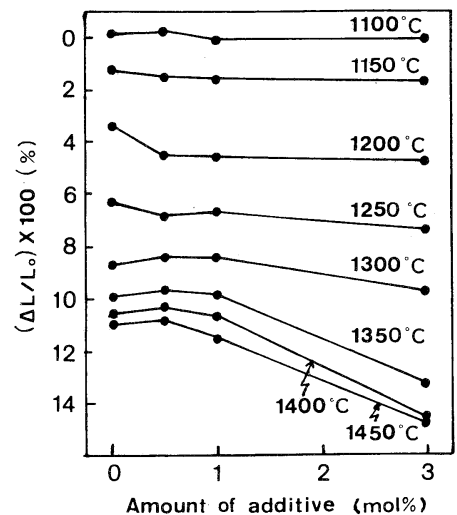

Fig. 2. Isothermal shrinkage curves of $\mathrm{MgO}$ compacts with various amounts of $\mathrm{ZrP}_{2} \mathrm{O}_{7}$ added (heating rate $: 10^{\circ} \overline{\mathrm{C}} \cdot \mathrm{min}^{-1}$ ).

diffractometry. It seems that the amounts of those compounds are too small to be detected by the X-ray diffractometry and/or that an amorphous phase whose composition ratio of $\mathrm{MgO} / \mathrm{P}_{2} \mathrm{O}_{5}$ is 1 to 2 may be present.

Figure 2 shows the isothermal shrinkage curves of $\mathrm{MgO}$ compacts with various amounts of $\mathrm{ZrP}_{2} \mathrm{O}_{7}$ addition. $\mathrm{Up}$ to $1300^{\circ} \mathrm{C}$, little effect of $\mathrm{ZrP}_{2} \mathrm{O}_{7}$ addition on the shrinkage behavior of the $\mathrm{MgO}$ compact was detected. However, further heating promoted the densification of the $\mathrm{MgO}$ compact with $3.0 \mathrm{~mol} \% \mathrm{ZrP}_{2} \mathrm{O}_{7}$ addition.

From the SEM observation an appreciable amount of the liquid phase was observed to be formed above $1300^{\circ} \mathrm{C}$. The liquid phase formed in this temperature region may consist of $\mathrm{MgO}$ and $\mathrm{Mg}_{3}\left(\mathrm{PO}_{4}\right)_{2}{ }^{12)}$. Thus the densification of the $\mathrm{MgO}$ compact is found to be promoted by the liquid phase in the $\mathrm{MgO}-\mathrm{Mg}_{3}\left(\mathrm{PO}_{4}\right)_{2}$ system.

\subsection{Changes in the relative density and porosities}

Figure 3 shows the relative density, the total porosity, the open porosity and the closed porosity of $\mathrm{MgO}$ compacts, with various amounts of $\mathrm{ZrP}_{2} \mathrm{O}_{7}$ added, sintered at $1450^{\circ} \mathrm{C}$ for $5 \mathrm{~h}$.

The relative density of $\mathrm{MgO}$ decreased with an increase in the amount of additive from 0 to $0.5 \mathrm{~mol} \%$, whereas it increased with a further increase in the amount of additive up to 3.0 mol\%. The change of the total porosity is contrary to that of the relative density : the total porosity of $\mathrm{MgO}$ showed a maximum value at $0.5 \mathrm{~mol} \% \mathrm{ZrP}_{2} \mathrm{O}_{7}$ addition. A similar result was also obtained in the measurement of the open

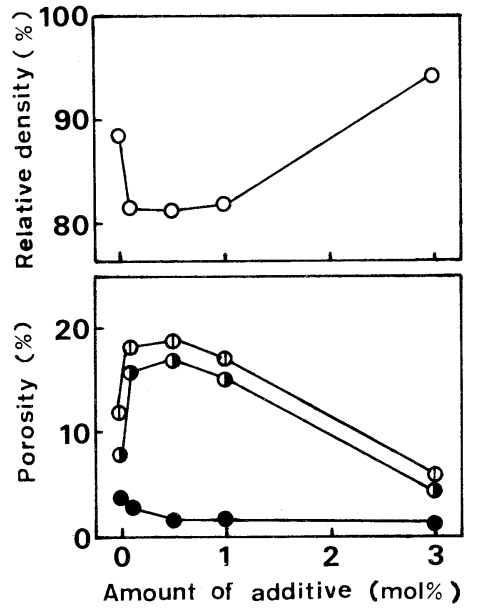

Fig. 3. Changes of relative density and porosities of $\mathrm{MgO}$ compacts, with various amounts of $\mathrm{ZrP}_{2} \mathrm{O}_{7}$ added, sintered at $1450^{\circ} \mathrm{C}$ for $5 \mathrm{~h}$.
(1): Total porosity,
- Open porosity,
: Çlosed porosity

porosity. The closed porosity appeared to show a slight reduction with increasing the amount of additive.

A behavior similar to this swelling may be observed when small amounts of the liquid which formed during sintering have a high wetting angle ${ }^{13)}$. An increase in the liquid contents promotes the rearrangement of grains which leads to a closer packing ${ }^{13)}$. Therefore, a marked effect of the rearrangement of the grains may be expected for the sintering of $\mathrm{MgO}$ with $3.0 \mathrm{~mol} \% \mathrm{ZrP}_{2} \mathrm{O}_{7}$ addition. In addition, the change of the total porosity is found to be affected more by changes of the open porosity than by changes of the closed porosity. The EPMA showed that $\mathrm{Zr}$ and $\mathrm{P}$ concentrated in the region of the grain boundaries in the case of $3.0 \mathrm{~mol} \% \mathrm{ZrP}_{2} \mathrm{O}_{7}$ addition. It can be said from these results that the liquid phase does not contribute to the elimination of the open pores until it surrounds the grains by adding 3.0 $\mathrm{mol} \% \mathrm{ZrP}_{2} \mathrm{O}_{7}$.

Figure 4 shows the etched surfaces of pure $\mathrm{MgO}$ compact and of the $\mathrm{MgO}$ compact with 3.0 mol\% $\mathrm{ZrP}_{2} \mathrm{O}_{7}$ addition sintered at $1450^{\circ} \mathrm{C}$ for 5 h. The photograph (a) of the pure $\mathrm{MgO}$ revealed that the grains had irregular shapes and were about $10-20 \mu \mathrm{m}$ in size. Pores whose mean diameter was about $5 \mu \mathrm{m}$ were located at the grain boundaries and in the bulk of the grains. The photograph (b) of $\mathrm{MgO}$ with $3.0 \mathrm{~mol} \%$ 

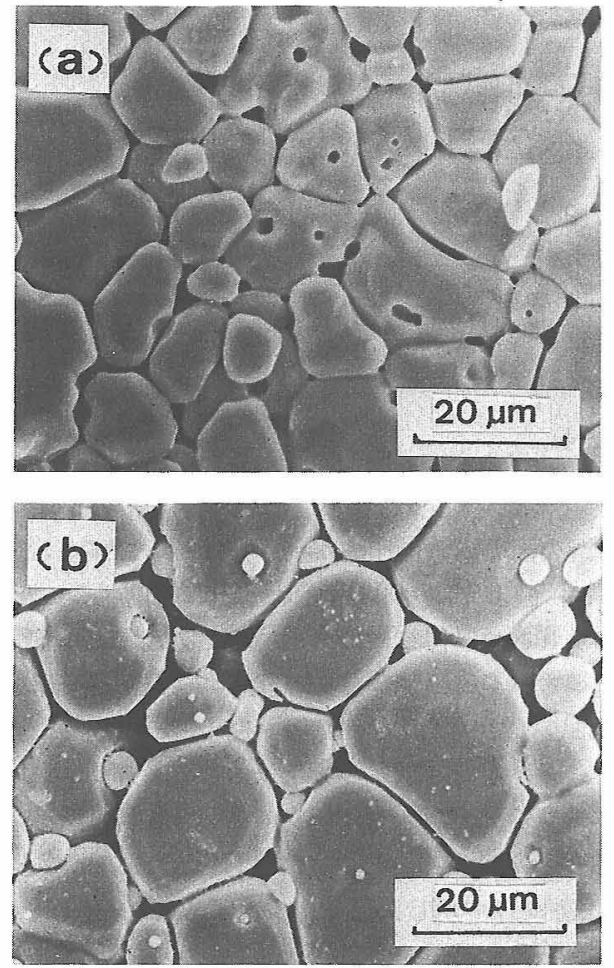

Fig. 4. Etched surfaces of (a) $\mathrm{MgO}$ compact and (b) $\mathrm{MgO}$ compact with $3.0 \mathrm{~mol} \% \mathrm{ZrP}_{2} \mathrm{O}_{7}$ addition sintered at $1450^{\circ} \mathrm{C}$ for $5 \mathrm{~h}$.

$\mathrm{ZrP}_{2} \mathrm{O}_{7}$ addition showed that smaller grains were present in the intergranular regions between larger grains, to give a closer packing. Few pores were located in the bulk of the grains.

As shown in Fig. 4, the liquid phase promotes the rearrangement of the grains, which also contributes to the elimination of pores. In addition, the solution and precipitation of grains is considered to take place simultaneously in the presence of the liquid phase ${ }^{14}$. This process will continue until the smaller grains disappear and will produce uniform grains ${ }^{14}$.

\section{Conclusion}

The sintering of $\mathrm{MgO}$ with $\mathrm{ZrP}_{2} \mathrm{O}_{7}$ addition was studied in the presence of the liquid phase at and below $1450^{\circ} \mathrm{C}$.

The densification of $\mathrm{MgO}$ was affected by the $\mathrm{ZrP}_{2} \mathrm{O}_{7}$ addition above $1300^{\circ} \mathrm{C}$ : the densification was inhibited by the addition of $1.0 \mathrm{~mol} \%$ or less $\mathrm{ZrP}_{2} \mathrm{O}_{7}$, whereas it was promoted by the further increase in the amount of additive up to $3.0 \mathrm{~mol} \%$.

The liquid phase in the $\mathrm{MgO}-\mathrm{Mg}_{3}\left(\mathrm{PO}_{4}\right)_{2}$ system was formed above $1300^{\circ} \mathrm{C}$ : it did not contribute to the densification of the $\mathrm{MgO}$ compact until the liquid surrounded the grains. A large amount of the liquid had an appreciable effect on the rearrangement of $\mathrm{MgO}$ grains and on the elimination of open pores.

\section{References}

1) K. Hamano, Bull. Ceram. Soc. Jpn., 7, 231-42(1972).

2) W. D. Kingery, J. Am. Ceram. Soc., 33, 239-50 (1950).

3) J.E. Lyon, T. U. Fox and J.W. Lyons, Am. Ceram. Soc. Bull., 45, 1078-81 (1966).

4) V.M. Ust' yantsev, M. G. Tretnikova, E. I. Kelareva and L.I. Mangalova, Ogneupory, 1978, No. 5, 51-58 (1978).

5) M. Găsić and F. Sigulinski, Ceram. Int., 2, 184-89 (1976).

6) M. Kinoshita and K. Itatani, Yogyo-Kyokai-Shi, 88, 388-94 (1980).

7) M. Kinoshita and K. Itatani, Yogyo-Kyokai-Shi, 90, 463-69 (1982)

8) M. Kinoshita and K. Itatani, Yogyo-Kyokai-Shi, 90, 570-75 (1982)

9) R.F. Deacon, S.F.A. Miskin and B. J. Ladell, Trans. J. Brit. Ceram. Soc., 65, 585-601 (1966).

10) M. Sugai and S. Sōmiya, Yogyo-Kyokai-Shi, 90, 420-26 (1982).

11) C. F. Grain, J. Am. Ceram. Soc., 50, 288-90 (1967).

12) J. Berak, Rocz. Chem., 32, 17-22 (1958).

13) W. J. Huppmann and H. Riegger, Acta Metall., 23, 965-71 (1975)

14) W. D. Kingery, J. Appl. Phys., 30, 301-06 (1959). 